\title{
A Study on the Profile Characteristics of the Farmers using Information and Communication Technologies (ICTs)
}

\author{
K. Madhuri*, S. V. Prasad, V. Sailaja, A. Pratap Kumar Reddy and G. Mohan Naidu
}

Department of Agricultural Extension, Acharya N G Ranga Agricultural University, S. V. Agricultural College, Tirupathi-517502, India

*Corresponding author

\author{
A B S T R A C T
}

\section{Keywords}

Farmers, small and Medium farming, Social participation

Article Info

Accepted:

26 May 2020

Available Online:

10 June 2020
The present study was conducted in Chittoor, Guntur and Vishakapatnam districts of Andhra Pradesh to study the profile of the farmers using ICTs. Total 240 respondents were randomly selected for the study interviewed. Most of the respondents were middle aged (67.50\%), had middle school education $(35.00 \%)$, small farmers $(38.34 \%)$ with medium farming experience $(59.17 \%)$, annual income $(45.00 \%)$, cosmopoliteness $(70.83 \%)$, possession of ICT tools $(58.34 \%)$, had not undergone training $(55.00 \%)$, social participation $(58.34 \%)$, extension contact $(69.83 \%)$, mass media exposure $(53.33 \%)$, innovativeness $(63.33 \%)$, economic orientation $(59.16 \%)$, risk orientation $(69.58 \%)$, scientific orientation $(70.42 \%)$.

\section{Introduction}

The farmers as producers of food must have an enabling environment for access to knowhow and do-how for realizing the full potential of modern agricultural technology and should be empowered in taking initiatives and decisions which will only help in shaping the future of farmer's economy. In the present scenario of Indian agriculture, the public extension cannot possibly provide additional qualified manpower to adequately address the complex demand of the farmers by reaching the millions of farmers. Farmer's needs are much more diversified and the knowledge required to address them is beyond the capacity of the grass root level extension functionaries. These weaknesses or draw backs focus on the use of alternative means of value added and demand-driven information to farming community.

The need of the hour is the use of modern and quick communication channels like ICTs to disseminate and create awareness about latest farm technologies among rural mass. There are umpteen ways in which ICTs can be useful to small and marginal farmers in India. 
The effective awareness campaign on ICT use, involvement of local self-governments, value added information and combination of services provision proved as strategic factors behind success of ICT initiatives.

\section{Materials and Methods}

In the present study Ex-post facto research design was followed. Ex-post facto research is a systematic empirical enquiry in which the scientists do not have control of influencing independent variables, because manifestation have already occurred.

The Andhra Pradesh state was chosen as the locale of the study, since the researcher belongs to the state and was familiar with the local language and culture. All the three regions in the newly formed state of Andhra Pradesh viz., Rayalaseema, Coastal Andhra and North Coastal region were included for the present study.

One district from each region was selected by following lottery method of simple random sampling procedure. The names of the selected districts were Chittoor from Rayalaseema region, Guntur from Coastal region and Visakapatnam from North Coastal region.

From each of the selected district, two mandals were purposively selected based on the highest are under cultivation. The sample constituted to a total of six mandals. From each of the selected mandal, four villages were selected by following lottery method of simple random sampling procedure.

The sample constituted to a total of twenty four villages. From each of the selected village, ten farmers were selected by following lottery method of simple random sampling procedure. The sample constituted to a total of 240 respondents.

\section{Results and Discussion}

Age

It could be seen from the table 1 that, majority 67.50 per cent of the farmers belonged to middle age category, followed by old age $(18.33 \%)$ category and young age $(14.17 \%)$ categories. Majority of the farmers were under middle age category because most of the old age people are not able to use ICTs. Another reason may be middle age people are enthusiastic and have more use of ICTs for getting information related to agriculture and allied activities.

Moreover, these people have more family responsibility and sensibility. They also work with a sense of commitment and involvement. The findings of the present study were similar with the studies of Richakumari (2017).

\section{Education}

Table 1 clearly depicted that, 35.00 per cent of the farmers had completed their middle school education, $(24.15 \%)$ had complete their high school education, $(19.60 \%)$ were in can read and write category, $(12.50 \%)$ had completed their college education followed by illiterates $(8.75 \%)$.

Majority of the respondents were educated. This may be because of functioning of government and private aided schools in the study area and few of the respondents would have studied in colleges situated in nearby towns. Only few of the respondents found to be illiterate due to poverty. The results were in line with findings of Vivek (2017).

\section{Land holding}

It could be elucidated from table $1,38.34$ per cent of the farmers were small farmers followed by marginal (32.50\%) and large 
(29.16\%) farmers. It could be inferred from the results that the sub division and fragmentation of the farm land from one generation to another generation was the reason for declining the size of land holding. This might be the probable reason for majority having small land holdings. The results were in confirmation with the findings reported by Patra et al., (2016).

\section{Farming experience}

It could be indicated from the table 1 that, majority 59.17 per cent of the respondents were grouped under medium farming experience followed by low (24.16\%) and high $(16.67 \%)$ farming experience. This might be due to the fact that that agriculture is the main occupation for the farmers. They are doing this activity for decades together. The findings of the study were in conformity with the studies of Chikaire et al., (2015).

\section{Annual income}

It is evident from the table 1 that, 45 per cent of the respondents had medium level of annual income followed by high level of income $(31.66 \%)$ and low level of annual income $(23.34 \%)$.

The probable reason, which could be attributed for varied income categories of respondents, might be due to size of the land holding, subsidiary occupations like dairy, poultry by the respondents. Another reason may be majority of the farmers were educated and they can think economic aspects of different enterprises. The findings of the present study were similar to that of Galande et al., (2014).

\section{Cosmopoliteness}

It could be inferred from the table 1 that, majority 70.83 per cent of the farmers had medium level of cosmopoliteness, followed by high $(20.83 \%)$ and low $(8.34 \%)$ level of cosmopoliteness. The farmers using ICTs are fairly good in their socio- economic status and they would travel frequently to near by towns and cities for obtaining required inputs and marketing the produce and also nearness of the town may be one of the reason. Hence the cosmopoliteness level was medium. Similar findings were communicated in the studies of Nayak et al., (2014)

\section{Possession of ICT tools}

From the table 1, indicated that, majority 58.34 per cent of the respondents belonged to medium possession of ICT tools category followed by low (22.50\%) and high (19.16\%) possession of ICT tools category.

On-going developments in the field of ICT might have attracted the farmers towards use of different ICT tools. The utilization pattern as well as knowledge might have influenced the degree of possession of different ICT tools by the farmers.

\section{Trainings undergone}

An over view of table 1, revealed that, 55 per cent of the respondents had not undergone training followed by $(45.00 \%)$ had undergone training respectively. This might be due to lack of awareness among the farmers regarding the usefulness of the training programmes, farmers being busy with their farm operations, lack of interest in spending their time to participate in the training programmes. The result was in confirmation with the results of Sarada and Prabakar (2009).

\section{Social participation}

It is apparent table 1, that illustrated that, majority 58.33 per cent of the respondents 
had medium level of social participation, followed by low (21.25\%) and high $(20.42 \%)$ level of social participation. From the results it could be inferred that majority of farmers tend to become members in social organizations Viz., co-operative agricultural credit societies, farmers discussion groups, panchayat union etc., mainly to avail the benefits given by the organization irrespective of their interest in such organizations. This might be the probable reason for the medium level of social participation among majority of the respondents. The result was in confirmation with the results of Tomar et al., (2016) and Verma et al., (2016).

\section{Extension contact}

An over view of table 1 indicated that majority 69.83 per cent of the farmers had medium level of extension contact, followed by those high (17.67\%) and low (12.50\%) extension contact.

In spite of having well established extension network in the recent past still about one-third of farmers were unable to access the extension services. This might be due to lack of awareness on extension services or the lack of interest in consulting the extension officials. The overall trend reflects the scope for enhancing the quality and quantity of extension system through appropriate strategies. The present education status and desire for the modern technologies might be motivating the farmers towards building up of regular extension contacts. The result was in confirmation with the results of Kabir (2015).

\section{Mass media exposure}

The findings presented in table 1, clearly indicated that 53.33 per cent of the respondents had medium level of mass media exposure followed by low (30.00\%) and high $(16.67 \%)$ exposure to mass media.
The reason for medium level of mass media exposure of farmers may be due to medium level of education as revealed in the study and also maximum interest in current issues and new technology. Farmers are very much dependent on mass media not only as a source of news and information, but also as a source of entertainment and leisure.

They help to update latest developments which are a good sign and speak about interest of farmers to view the things. The research findings were in correspondence with the studies of Angadi and Viswatej (2013)

\section{Innovativeness}

The results from the table 1 indicated that, majority 63.33 per cent of the farmers had medium level of innovativeness, followed by high $(19.17 \%)$ and low $(17.50 \%)$ innovativeness. This trend might be due to the farmers are quite receptive to any of the technological breakthrough in terms of crop cultivation for higher returns.

In addition, the medium level of education of the farmers which helped them to try new technologies that are disseminated through ICTs on their fields. Further, the farmers might be interested to try new innovations to increase their income. Hence, the farmers inclined towards the technologies disseminated through ICTs which fetch them more income which might have prompted them to have medium level of innovativeness. Dhaka and Chayal (2010)

\section{Economic orientation}

It could be inferred from table 1 that, majority 59.16 per cent of the farmers had medium level of economic orientation, followed by high $(25.00 \%)$ and low (15.84 \%) economic orientation. 
Table.1 Distribution of farmers according to their profile characteristics

\begin{tabular}{|c|c|c|c|}
\hline S.No & Category & Frequency & Percentage \\
\hline \multicolumn{4}{|l|}{ Age } \\
\hline 1 & Young age & 34 & 14.17 \\
\hline 2 & Middle age & 162 & 67.50 \\
\hline 3 & Old age & 44 & 18.33 \\
\hline \multicolumn{4}{|c|}{ Education } \\
\hline 1 & Illiterate & 21 & 8.75 \\
\hline 2 & Can read and write & 47 & 19.60 \\
\hline 3 & Middle school & 84 & 35.00 \\
\hline 4 & High school & 58 & 24.15 \\
\hline 5 & College education & 30 & 12.50 \\
\hline \multicolumn{4}{|c|}{ Land holding } \\
\hline 1. & Marginal farmers & 78 & 32.50 \\
\hline 2. & Small farmers & 92 & 38.34 \\
\hline 3. & Big farmers & 70 & 29.16 \\
\hline \multicolumn{4}{|c|}{ Farming experience } \\
\hline 1. & Low farming experience & 58 & 24.16 \\
\hline 2. & Medium farming experience & 142 & 59.17 \\
\hline 3. & High farming experience & 40 & 16.67 \\
\hline \multicolumn{4}{|c|}{ Annual income } \\
\hline 1 & Low annual income & 56 & 23.34 \\
\hline 2 & Medium annual income & 108 & 45.00 \\
\hline 3 & High annual income & 76 & 31.66 \\
\hline \multicolumn{4}{|c|}{ Cosmopoliteness } \\
\hline 1 & Low cosmopoliteness & 20 & 8.34 \\
\hline 2 & Medium cosmopoliteness & 170 & 70.83 \\
\hline 3 & High cosmopoliteness & 50 & 20.83 \\
\hline \multicolumn{4}{|c|}{ Possession of ICT tools } \\
\hline 1 & Low possession of ICT tools & 54 & 22.50 \\
\hline 2 & Medium possession of ICT tools & 140 & 58.34 \\
\hline 3 & High possession of ICT tools & 46 & 19.16 \\
\hline \multicolumn{4}{|c|}{ Trainings undergone } \\
\hline 1 & Undergone training & 108 & 45.00 \\
\hline 2 & Not undergone training & 132 & 55.00 \\
\hline \multicolumn{4}{|c|}{ Social participation } \\
\hline 1 & Low social participation & 49 & 21.25 \\
\hline 2 & Medium social participation & 140 & 58.33 \\
\hline 3 & High social participation & 51 & 20.42 \\
\hline \multicolumn{4}{|c|}{ Extension contact } \\
\hline 1 & Low extension contact & 30 & 12.50 \\
\hline 2 & Medium extension contact & 166 & 69.83 \\
\hline 3 & High extension contact & 44 & 17.67 \\
\hline \multicolumn{4}{|c|}{ Mass media exposure } \\
\hline 1 & Low mass media exposure & 72 & 30.00 \\
\hline 2 & Medium mass media exposure & 128 & 53.33 \\
\hline
\end{tabular}




\begin{tabular}{|c|l|c|c|}
\hline $\mathbf{3}$ & High mass media exposure & 40 & 16.67 \\
\hline \multicolumn{2}{|c|}{ Innovativeness } & & \\
\hline $\mathbf{1}$ & Low innovativeness & 42 & 17.50 \\
\hline $\mathbf{2}$ & Medium innovativeness & 152 & 63.33 \\
\hline $\mathbf{3}$ & High innovativeness & 46 & 19.17 \\
\hline Economic orientation & & \\
\hline $\mathbf{1}$ & Low economic orientation & 38 & 15.84 \\
\hline $\mathbf{2}$ & Medium economic orientation & 142 & 59.16 \\
\hline $\mathbf{3}$ & High economic orientation & 60 & 25.00 \\
\hline Risk orientation & & \\
\hline $\mathbf{1}$ & Low risk orientation & 54 & 7.92 \\
\hline $\mathbf{2}$ & Medium risk orientation & 167 & 69.58 \\
\hline $\mathbf{3}$ & High risk orientation & & 22.50 \\
\hline Scientific orientation & Low scientific orientation & 19 & 12.08 \\
\hline $\mathbf{1}$ & Medium scientific orientation & 42 & 70.42 \\
\hline $\mathbf{2}$ & High scientific orientation & & 17.50 \\
\hline $\mathbf{3}$ & & & \\
\hline
\end{tabular}

The reasons for the above finding might be due there is always an urge earn money in the minds of people to increase the socio economic status and improve their standard of living. The respondents of the study area were not exception to this kind of urge. This desire to compete with each other in improving their standard of living and to fulfil family commitments resulted in medium economic orientation. Similar findings were explored by Vivek (2017)

\section{Risk orientation}

It could be viewed from the table 1 , revealed that majority 69.58 per cent of the farmers had medium level of risk orientation, followed by high (22.50\%) and low (7.92\%) risk orientation.

In any situation, the risk is a part of life. But the degree of variation depends on the nature of activity and its way of handling by an individual. The medium to high risk orientation is a good indication as it is required to make the farming more profitable. The extension workers had to focus on the low risk orientation groups which are in good number and help them to improve their farm income. Similar findings were explored by Verma et al., (2016).

\section{Scientific orientation}

The keen observation from the table 1 showed that, majority 70.42 per cent of the farmers had medium level of scientific orientation, followed by high (17.50\%) and low (12.08\%) scientific orientation.

Scientific orientation leads to knowledge acquisition and which in turn may lead to adoption of new technology. Medium scientific orientation is a good indication of farmers to acquire new methods in farming and might have resulted in considerable income. A good number of respondents had high scientific orientation which is very much essential for successful farming. Better scientific orientation leads to better decision making in the farm operations. The findings of Kumar et al., (2012) were in line with the present study.

As per the study majority of the farmers had medium to low extension participation, mass media exposure and social participation and also majority of the respondents expressed that there is lack of training centers and trained manpower to teach about ICTs. Hence, developmental departments need to organize training programmes at village levels and make farmers to expose different services and more to 
acquaint with new ICTs along with providing consultancy services and good infrastructure facilities.

\section{References}

Chikaire, J.U., Ani, A.O., Nnadi, F.N. and Godson-Ibeji, C.C.2015. Analysis of Information and Communication Technology Roles in Poverty Reduction Among Small and Medium Scale Farmers in Imo State, Nigeria. Library Philosophy and Practice (e-journal).1-14.

Dhaka, B.L. and Chayal, K.2010. Farmers Experience with ICTs on Transfer of Technology in Changing Agri-rural Environment. Indian Research Journal Extension Education. 10 (3):114-118.

Galande, P.S., Ahire, M.C. and Patil, J.M. 2014.Extent of Utilization of Information by Dryland farmers. Journal of Communication Studies. XXXII (2): 93100.

Kabir, K.H. 2015.Attitude and Level of Knowledge of Farmers on ICT based Farming. European Academic Research. 2 (10): 13177-13196.

Kumar, P., Singh, P. and Mishra, O.P. 2012. Comparative Study of Knowledge Level of Marginal and Small farmers about Rice Production Technology.Journal of Communication Studies. XXXII (1): 120128.

Nayak, S.K., Rai, D.P. and Saxena, K.K. 2014.Impact of Mass Media on Adoption of Agricultural Technologies. Journal of Communication studies. XXXII (2): 8899.

Patra, J., Singh, D.V. and Patil, J.K. 2016.Kisan Mobile Advisory- An Effective ICT tool for Technology Dissemination. International Journal of Humanities and Social Science Invention.5 (6): 68-72.

Richakumari .2017. Role of information and communication in agricultural development- An analytical study at samistipur district of Bihar. MSc. (Ag) Thesis. Dr. Rajendhra Prasad central agricultural university, Pusa.

Sarada, O. and Prabhakar, K. 2009. Direct and Indirect Relationship of Farmers Personal, Psychological and Communication Characteristics and their Perceived Communication Effectiveness of Extensionists.The Andhra Agricultural Journal. 56 (3): 373-377.

Tomar, A., Bhardwaj, N., Verma, A.P. and Sawant, M.N. 2016.Association between Socio-Demographic Profile and Extent of Use of ICT among Farmers. International Journal of Agricultural Science and Research. 6(6): 163-168.

Verma, A.P., Ansari, M.A., Rajan, R., Archana, B., Rupan, R and Diksha, P. 2016. Farmers Attitude towards e-choupal: A Critical Investigation in Gonda District of Uttar Pradesh. International Journal of Agriculture Sciences. 8 (49):2076-2078.

Viswatej and Angadi.2013. awareness, accessibility and utilisation pattern of information and communication pattern (ICT) projects by farmers of belagum district. $M S c(A g)$ Thesis. UAS, Dharwad.

Vivek. 2017. Utilisation of information and communication technologies (ICTs) by the pea growers of patan block of Jabalpur district of Madhya Pradesh. Jawaharlal Nehru Viswa Vidhyalaya, Jabalpur.

\section{How to cite this article:}

Madhuri, K., S. V. Prasad, V. Sailaja, A. Pratap Kumar Reddy and Mohan Naidu, G. 2020. A Study on the Profile Characteristics of the Farmers using Information and Communication Technologies (ICTs). Int.J.Curr.Microbiol.App.Sci. 9(06): 3676-3682.

doi: https://doi.org/10.20546/ijcmas.2020.906.433 